\title{
LESSONS FROM CREATING A BUSINESS SCHOOL FOR PUBLIC GOOD: OBLIQUITY, WAYSETTING, AND WAYFINDING IN SUBSTANTIVELY RATIONAL CHANGE
}

\author{
MARTIN KITCHENER \\ RICK DELBRIDGE \\ Cardiff University, Cardiff, United Kingdom
}

\begin{abstract}
We apply Weber's distinction between instrumental (outcome focused) and substantive (values driven) rationality to offer both a conceptually underpinned explanation for the mounting criticism of business schools and to provide the basis for a new business school model. We begin by extending Brewer's (2013) treatise on the public good of social science to articulate a substantively rational public value business school. We then report how processes of waysetting, wayfinding, and strategic obliquity informed the iterative development of this approach at Cardiff Business School in the United Kingdom. Our case study illustrates the significant challenges and tensions that arise from trying to introduce a substantively rational approach and change process within an institutional context of instrumental rationality. Our analysis underscores the importance of combining both purposive action (away from the current) and substantively rational purposeful action (a direction of travel informed by particular values). It also highlights the potential for some business schools to combine substantive rationality with strategic obliquity in attempts to enhance public good through systemic, institutional change.
\end{abstract}

\begin{abstract}
"The normative public value of social science is that it nurtures a moral sentiment in which we produce and reproduce the social nature of society, enabling us to recognize each other as social beings with a shared responsibility for the future of humankind through understanding, explaining, analyzing and ameliorating the fundamental social problems stored up for us. Social science thus becomes a public good for its own sake for cultivating this moral sentiment and sympathetic imagination through its subject matter, teaching, research and civic engagements" (Brewer, 2013: 151).
\end{abstract}

Motivated by our desire to move beyond the mounting critiques of business schools (Ghoshal, 2005; Khurana, 2007; Parker, 2018) and to develop a purposeful way forward, our paper contributes to this special issue's theme of rationality in management education and learning by revisiting Weber's

We would like to acknowledge the considerable advancement to our thinking that has occurred during the review process and extend our thanks to the editors, in particular Mike Zundel, for his advice and constructive challenge.
(1978) distinction between instrumental (outcomefocused) and substantive (values-driven) rationality. We first apply it to produce a conceptually underpinned explanation for the current condition of many business schools, and from this advance an alternative approach founded on a commitment to enhancing the public good of business schools. We then provide a firsthand account of the processes of waysetting, wayfinding (Chia \& Holt, 2009), and strategic obliquity (Kay, 2010) that emerged during our iterative development and implementation of this approach at Cardiff Business School (CARBS) in the United Kingdom (UK). Our case study illustrates the significant challenges and tensions that arise from trying to introduce a substantively rational approach and change process within an institutional context of instrumental rationality. Our analysis highlights the importance of combining both purposive action (movement away from the current instrumental rationality that pervades business schools) and substantively rational purposeful action (movement in a direction of travel informed by particular value commitments, in this case public good). 
The paper provides contributions to our comprehension of the current circumstances of business schools, the possibilities for change that embrace a commitment to the public good of business schools, and an extension of our understanding of processes of oblique and substantively rational change. First, our analysis offers an underpinning explanation for the various critiques of contemporary business schools; that is, their instrumentally rational orientation prioritizing quantitative performance indicators results in a variety of undesirable outcomes. This understanding is vital to determine the basis for purposive action (what needs to be left behind). Second, we draw on Brewer's (2013) arguments for the public value of social science to outline an alternative approach for business schools: one which is orientated around this value and the delivery of public good. Third, we build from the insights of Chia and Holt (2009) and Kay (2010) on oblique and emergent change to interpret the change processes that unfolded at CARBS. This offers an elaboration of previous work in introducing and highlighting the significance of "waysetting" alongside wayfinding; that is, the establishment of the underpinning value orientation and direction of travel for emergent strategy development. This also allows the further development of the link between purposive and purposeful action that is introduced by Chia and Holt (2009). Specifically, we show how substantively rational action, in the form of waysetting, can facilitate the move from purposive to purposeful action.

The paper is presented in three main parts. We begin by explaining how we applied the Weberian view of rationality in two ways: First, as the conceptual basis of our argument that because criticisms of business schools arise from their instrumentally rational operations, resolution should be sought from new models resting on substantively rational action. Second, to provide a post hoc means of characterizing the nature and process of our reported change in substantively rational terms.

The second part of the paper presents our analytical autoethnographic (Anderson, 2006) account of why and how we attempted to direct CARBS' activities toward enhancing public good in a strategically oblique process we describe as "waysetting." We then explain how subsequently, through processes of collective and largely collaborative wayfinding, a public value business school (PVBS) approach was developed and enacted at CARBS. The case shows the tensions arising when trying to introduce a substantively rational approach and change process in the current political economy of higher education. We conclude by drawing lessons on the potential for some business schools to combine substantive rationality and strategic obliquity as a basis for attempts to enhance the public good.

\section{INTERPRETING BUSINESS SCHOOLS THROUGH THE CONCEPT OF RATIONALITY}

Reference to reason in management education and practice has been dominated by conventional notions of instrumental rationality (Joullie, 2016) that fit the "zweckrational" orientation described by Weber (1978: 24). From this perspective, actions are seen as instrumentally rational when the actor systematically calculates various outcomes before selecting the optimal means to a desired end. Weber contrasted zweckrational with "wertrational" or substantive rationality, the rational orientation to an absolute value. Following Kalberg (1980: 1155), we interpret Weber's substantive rationality as inherently action-orientated because it "directly orders action into patterns. It does so, however, not on the basis of a purely means-end calculation of solutions to routine problems but in relation to a past, present or future value postulate." Although the substantive form of rational action has been underplayed in analyses of business and management (Derry, 1989; Carruthers \& Espeland, 1991), Biggart and Delbridge (2004: 34) observe:

\footnotetext{
"Substantive rationality can, like instrumental rationality, be calculating and employ reason, but a substantive or ethical good (e.g., greening the economy, redistributing income, caring for employees) is at its base. Substantively rational action is rational in the sense that action is predictable and not capricious, but it need not follow the procedural rigor of instrumental rationality, and actors often feel morally or emotionally bound to pursue the substantive goal (e.g., fight poverty), even if they are not successful in achieving the end. The probability of success is not critical to substantive rationality, whereas it is always part of the calculus of instrumental rationality."
}

On reflecting on the change process reported later here, we have come to conceive our PVBS approach as a substantively rational alternative to the instrumentally rational model that Cardiff had shared with many schools. This view was developed through engagement with debates about the purpose, morality, legitimacy, and effectiveness of business schools that have been hosted in $A M L E$ and elsewhere (Ghoshal, 2005; Akrivou \& Bradbury-Huang, 2015; Alajoutsijarvi et al., 2015, 2018; Joullie, 2016; Harley, 2019). In a key contribution to our thinking, Arielli and colleagues' 
(2016) demonstrate that, notwithstanding variations that exist among the world's 13,000 business schools (Kaplan, 2018), managerial and isomorphic pressures including accreditation (Alajoutsijarvi et al., 2018) have led to convergence around a common emphasis on improving outcomes, such as student fee income, graduate salary premia (component of graduate's salary attributed to degree award), and rankings performance.

Our application of Weberian modes of rationality to Arielli and colleagues' (2016) findings provided two key insights. First, it suggested that the dominant form of instrumental rationality in business schools is not inevitable: It could be contrasted with a substantive rationality that orientates action toward some ethical value. Second, Arielli and colleagues' (2016) work provided empirical support for our view that the instrumental rationality of business schools helps to explain why they have been criticized for various failings including: domain-based teaching in which the creation of (narrower) shareholder value is privileged over (broader) stakeholder value (Fotaki \& Prasad, 2015); research that is typically market-driven and contained within a single discipline (Ghoshal, 2005; Pettigrew \& Starkey, 2016; Currie et al., 2016); engagement with a narrow set of elite partners (Khurana, 2007; Aguinis et al., 2014); and a reliance on a model of governance that prioritizes accreditation and ranking outcomes over the development of more progressive approaches to management that some schools teach, such as collaborative leadership (Parker, 2018).

Despite the mounting critiques of business schools outlined above, few coherent and robust examples of radical alternatives have emerged (Ferlie et al., 2010). For those business school leaders who recognize that their schools have "lost their way," it remains unclear in which direction they might "head" (Alajoutsijarvi et al., 2018: 219). From our perspective, this may be explained in part, because modes of rationality have not been considered as both the explanation for current conditions and as the basis for an alternative business school approach. In an argument that is complementary to ours, Harley (2019: 291) asserts that "formal rationality appears increasingly to define the contemporary business school," however, in his proposals for change he focuses on individuals' actions and does not propose an alternative institutional model. In our view, individual, institutional, and systemic change are all needed.

From our contention that substantively rational business school approaches are required to address the critiques of the instrumentally rational model, we now proceed to outline a post hoc conception of the change process we report in substantively rational terms.

\section{A SUBSTANTIVELY RATIONAL APPROACH TO CHANGE:}

\section{Obliquity, Waysetting, and Wayfinding}

We have come to appreciate that the change process we report here was substantively, rather than instrumentally, rational because although we knew what value commitment underpinned our ambitionsand to some extent we had an idea of the "end" we wanted to achieve (a new business school approach based on the substantively rational delivery of public good) - we were not clear how to conceptualize or articulate that "end," nor did we have indicators of the intended outcomes or specifics on how to achieve them. We now recognize this as an "oblique" approach in that:

"Complex objectives tend to be imprecisely defined and contain many elements that are not necessarily or obviously compatible with each other, and that we learn about the nature of objectives and the means of achieving them during a process of experiment and discovery" (Kay, 2010: 3-4).

Organizational change under such an approach is pursued in an indirect, or oblique, manner, rather than in a fully planned, top-down and linear way. Our case reports a rare empirical example of Kay's (2010) obliquity concept and also offers three points of elaboration and extension to Chia and Holt's (2009) adjacent "strategy without design" perspective. First, we empirically illustrate the potential for strategic obliquity to accommodate the two forms of action that Chia and Holt (2009: 92) view as discrete: purposive action is that taken to move away from a negative situation, and purposeful action is that taken to move toward a desired state. Our approach involved both a move away from the instrumentally rational approach that characterized our school (and many others), and a move toward an alternative, substantively rational model based on enhancing public good. Second, in an extension of Chia and Holt's concept of wayfinding, we term the direction-setting for the purposeful action that we engaged in as "waysetting" and provide empirical illustrations of both conceptual waysetting and wayfinding processes.

Third, we provide empirical illustration of the potential for obliquity to inspire colleagues to develop innovative outcomes through their "local coping actions" (Chia \& Holt, 2009: 24). We see the approach that resulted in our case as close to the "distributed practical wisdom" described by Nonaka and Toyama 
(2007: 371) in that our initial commitment to a vision for the future was given substance by the collective wayfinding of organizational members. It is here that our case most closely mirrors Chia and Holt's (2009) strategy without design perspective. In contrast to the conventional conception of change leaders as allseeing strategic "navigators" who try to use maps to plot a precise course toward a specified destination, we saw ourselves (and increasingly our colleagues) as "wayfinders" who anticipate the need to progress tentatively, tolerate ambiguity, cope with the frustrations of not being in full control, and allow for some "detours, lingerings, and directional changes" (Chia \& Holt, 2009: 173).

\section{PUTTING SUBSTANTIVE RATIONALITY INTO PRACTICE}

Having explained our post hoc conceptions of the substantively rational nature of the change process at CARBS, we now draw on those ideas to help frame our case analysis. Our research approach is consistent with that labeled "analytic autoethnography." Anderson (2006: 378) identifies the following five key features of such an approach: (1) "complete member" researcher status, which is contrasted with ethnographers whose participation in the field is temporary and partial; (2) analytic reflexivity; (3) narrative visibility of the researcher's self; (4) dialogue with informants beyond the self; and (5) commitment to theoretical analysis. This method has been distinguished from "evocative autoethnography” (Learmonth \& Humphreys, 2011: 105) and research that focuses on "autobiographical identity work" (Watson, 2009: 425), where the researcher's emotions and identity are central features.

Our approach is analytic and reflexive; in part it mirrors that adopted by Learmonth and Humphreys (2011: 114, footnote 8) in that our narrative was "constructed, initially from memory, and subsequently evolved through discussions with one another, and also from presentations of proto-versions at various conferences." In addition, and reflecting Anderson's (2006) fourth feature of analytic autoethnography, we have shaped and revised our case study through discussions with others who were part of our "field." As we have done so, we have engaged in a process of theorization of the case material. Our approach is thus explicitly consistent with that of analytic autoethnography and retains a commitment to analysis and to improving theoretical understanding of the phenomenon under examination (see Anderson, 2006, and Learmonth \& Humphreys, 2011, for the debates on evocative and analytic autoethnography). We should stress that these discussions with colleagues do not produce a single shared narrative. We report some divergences of view in the case below (also see Marinetto \& Dallyn, 2017). And although we are not claiming our view is "the truth," we refer to reports and activities that are described on publicly available websites in order that readers can see more of what has been done. Ultimately, as is the case with all autoethnography, we recognize that we are a part of the representational processes in which we are engaging and part of the story we are telling (see Atkinson et al., 2003).

Our case material is thus a combination of iterative reflections, extensive dialogue with colleagues, and retrospective analysis of data including meeting notes and internal documents (see Alajoutsijarvi et al., 2018, for a similar approach). Our engagement with the empirical world combined our roles as "complete members" (Anderson, 2006: 378) with our scholarly interests in organizational analysis. Through these connections to social science theory, we have sought analytical reflexivity to develop theoretical understanding of broader social phenomena. For us though, participation rather than analysis dominated through the period of change that we report and was only occasionally, and then retrospectively, complemented with the reflection and analysis reported here.

Our case is presented in two main parts: We begin by introducing the context for change and our conceptual waysetting that used Brewer's (2013) conception of the public good of social science to articulate a substantive rationality business school approach. In the second part, we illustrate some areas of progress and the significant challenges and tensions that arise from trying to find a way to introduce a substantively rational model within a countervailing institutional context.

\section{CONTEXT}

\section{Purposive Action Away From Instrumental Rationality}

In 2012, we were both working as professors at CARBS (see Table 1 for main characteristics of the school at that time) and serving on the School's senior management team (SMT). Kitchener was professor of public service management and led the School's external relations. Delbridge was professor of organizational analysis and led research. During the summer, a new vice chancellor (VC, akin to a 
university president) was appointed to lead our parent institution, Cardiff University. The incoming VC, a German scholar who arrived having held the VC role at another UK university, immediately launched his "Way Forward Strategy" (Cardiff University, 2012). A more rationally instrumental strategic approach would be hard to imagine. The stated goal was the achievement of an outcome (a top-100 world university ranking), and this was to be secured through 11 key performance indications (KPIs). In an interview with the student newspaper, the VC described his plans in exactly the terms of Chia and Holt's (2009) strategic navigator, likening his strategy to a roadmap "which outlines how we get from here to there by ... coordinating our efforts so that we get consistency" (Gair Rhyd, 2012:1).

To implement his instrumental strategy, the VC applied two standard moves from the New Public Management (NPM) playbook: a topic Kitchener had researched for more than 2 decades (Kitchener, 2002; Kitchener et al., 2000). First, following the NPM principle of enhancing managerial control over professional work through structural centralization, Cardiff University's 27 academic schools were subsumed into one of three new colleges. Immediately, the direct line of communication between the Dean of CARBS and the VC (see Table 1) was severed, and a new tier of bureaucracy formed at the College level (ironically contra to the NPM principle of delayering). Second, in line with the NPM principle of trying to improve performance by setting and monitoring outcome targets, all of Cardiff University's schools were informed of their requirement to contribute to the attainment of the University's KPIs (Cardiff Business School, 2013).

Following the appointment of the (then) Dean of CARBS to lead the new College of Arts, Humanities, and Social Sciences in 2012, we were both appointed to new leadership positions. Kitchener became Dean of CARBS, and Delbridge became University Dean of Research, Innovation, and Enterprise. We were both attracted to the roles by what we perceived to be an opportunity to draw on our research experience to introduce new thinking into university leadership. Kitchener was particularly interested in introducing a value-based school strategy (Ghoshal, 2005; Moore, 1995) in contrast to the instrumental NPM approaches he had been researching. In a similarly substantively rational approach, Delbridge was looking to strengthen interdisciplinary and challenge-led research across the university, drawing in part on his research on the organization and management of innovation (Price \& Delbridge, 2015). Then, in the autumn (Fall), as we were bedding into our new roles, the new college-level administration translated the University's KPIs into an expanded set of school-level targets, covering areas such as income growth and academic-ranking performance (Cardiff Business School, 2013).

\section{A Dean's Dilemma}

At the first meeting between Kitchener and his head of college in October 2012, the former was told that his first priority was to design and implement a new school strategy "to support the University's strategy." With no timescale given, and little further detail provided, Kitchener felt that he was being asked to devise a strategy for delivery of the University's KPIs at the school-level. He had learned, from attending a deans' training program and speaking with other deans, that there was a growing expectation in U.K. universities that business school deans should "stand and deliver" in this way. It was not, however, what he felt he had signed up for, and, at first glance, he thought it was neither efficacious, nor a particularly interesting way to spend the next chapter of his career.

In a conscious exploitation of the temporal latitude allowed by his head of college, Kitchener instigated a year-long strategic review of the School by way of extensive informal discussions, staff workshops, committee meetings, reading the business school literature in $A M L E$ and elsewhere, and engaging in interactions with external stakeholders. The clearest message to emerge was that despite the School's history of academic and financial success (see Table 1), CARBS faced significant threats both (a) externally, from the reduction of state financial support for universities, increased competition for staff, students, and research funding, and the mounting criticism of business schools, and (b) internally, through threats to its finances and autonomy from the instrumentally rational University strategy.

From CARBS' colleagues it emerged that there was a strong distaste for what was perceived to be the University's "managerialist KPI strategy," which was seen to give little regard to the Schools' distinctive contributions and character (see Table 1). Kitchener's academic research on NPM in various settings led him to believe that the University's strategic approach would certainly not be popular among academics, and it would be unlikely to deliver the stated outcomes. The combination of School sentiment and the Dean's research-informed view convinced him of the need to avoid replicating 
TABLE 1

Context for Change, Cardiff Business School in 2012

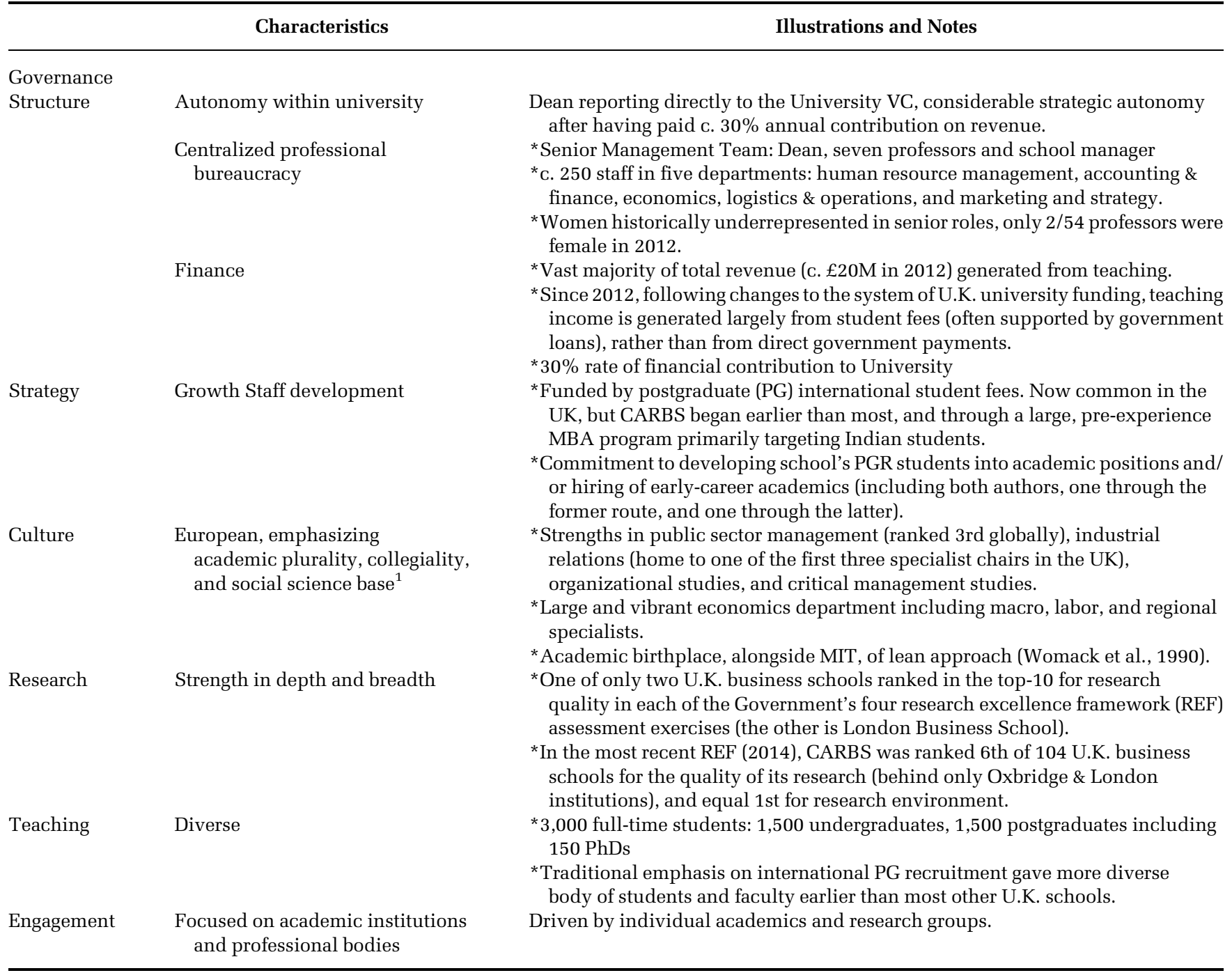

Source: ${ }^{1}$ Kaplan (2018).

the instrumental strategy of the University in the School, and instead, investigate the possibility of a values-led alternative (Bartlett \& Ghoshal, 1994; Moore, 1995). At the same time, however, the schoollevel KPIs made clear that he was not able to eschew the University's instrumentally rational prioritization of outputs. While this dilemma was clear to the Dean, its resolution was not.

\section{Addressing the Dean's Dilemma Through Conceptual Waysetting}

Recognizing the inherent tensions between the University's instrumental concerns for outcomes and his enthusiasm to develop a substantively rational school strategy, by early 2013 Kitchener had become resigned to the idea that a promising, but not ideal, way forward (sic) was to set a course that allowed the accomplishment of the University's KPIs and thereby maintain the autonomy and resources to support the School's pursuit of a valuesbased approach. The rest of this section explains how, from this compromised position, we collaborated to conceptualize and articulate an oblique and substantively rational approach to developing an alternative business school.

In the spring of 2013, as Kitchener was wrestling with his dean's dilemma, Delbridge's reading on interdisciplinary and challenge-led research led him to Brewer's (2013) call for social science to combine 
those features of scholarship to enhance public value. Having reflected on the implications that Brewer's ideas might have for how critical management studies could be conducted in ways more consequential for society (Delbridge, 2014), Delbridge emailed an electronic copy of Brewer's book to his friend and colleague and suggested he might find it interesting. On completing the book some weeks later, Kitchener responded: "I like it, what would a public value business school look like?" Delbridge replied, "I don't know, shall we find out?" During a series of discussions over the following months, we agreed that although Brewer does not discuss business schools directly, his analysis of the problems of social science were pertinent to address the malaise that had been ascribed to business schools by a variety of critics. In particular, Brewer's advocacy of ethical values in order that social science becomes normative and motivated by concern for a humanitarian future-and that these values should pervade research and teaching agendas so that they are designed to engage with all manner of publics and involve all stakeholders-stood in stark contrast to the picture painted by critics of conventional business schools. This gave us the basis for purposeful action and our "direction of travel." As Brewer (2013: 191) puts it, "The ethical commitments of the new public social science make it normative and partisan. These ethical values are explicit. They are its point."

Perhaps because Brewer's (2013) book does not explicitly address questions of rationality, we did not initially interpret Brewer's position in these terms. However, Delbridge had a long-standing interest in Weberian conceptions of rationality and how these inform social action (Biggart \& Delbridge, 2004). Through our discussions over time, we came to view Brewer's argument that the normative value of social science enhances public good as consistent with Weber's concept of substantive rationality where purposeful commitment to a substantive or ethical good lies at the heart of action. As Brewer notes, this involves social science returning to its 18th-century roots "with a moral vision committed to social and human improvement and betterment" (2013: 11).

Having interpreted Brewer's work as a call for social science organizations (in our case, a business school) to enhance public good by developing substantively rational approaches, we came to recognize that the course of action that Brewer's work inspired at CARBS can be interpreted as both a purposeful move toward the substantively rational pursuit of public good, and a purposive move away from the instrumental rationality that characterizes the operation of many business schools and our own university. This (re-)combination of the purposive and purposeful builds from the insights provided by Chia and Holt (2009) on emergent strategy. We extend their wayfinding approach by conceiving our initial conceptual work in setting the direction for purposeful change as "waysetting."

Although there was widespread agreement among CARBS colleagues that a move away from instrumental rationality was welcome, a variety of potential directions were suggested. Some senior economics professors advocated that the School declare UDI (unilateral declaration of independence) and seek to break from the parent university. Other colleagues expressed aspirations nearer to those captured recently in Parker's (2018) advocacy of "bulldozing" the business school. Of course, meeting the institutional expectation of "standing and delivering" KPIs was also an option, and one that appeared to have been taken at many other business schools. Our preference at this initial stage, without having a detailed conception of quite what would result or how it would develop, was to commit to a purposeful vision of the future that was underpinned by a clear value-based (i.e., substantively rational) orientation for action.

A particular challenge of such waysetting is that the general direction of travel is necessarily oblique, but it also needs to be clear enough to inspire colleagues to develop outcomes that align to the underpinning value commitments through their own processes of wayfinding. Kitchener's approach to this dilemma rested on translating Brewer's manifesto for change in social sciences into: (a) a substantively rational statement of purpose for a business school, and (b) supporting waymarks for the direction of travel in teaching, research, governance, and engagement (see Column 2, Table 2). Although these do not constitute a strategic navigator's "map," they do signal certain roads not taken.

The next section describes Kitchener's attempt to build on this initial conceptual waysetting to develop an understanding of a public value alternative business school and to find a way of introducing it at CARBS.

\section{From Waysetting To Wayfinding}

From 2015, the Dean's early iterations of a PVBS purpose statement and functional waymarks were discussed and revised with close colleagues including 
TABLE 2

Emergent Public Good Innovations at Cardiff Business School

\begin{tabular}{|c|c|c|}
\hline Function & PVBS Waymarks ${ }^{1}$ & Public Good Innovations (Year of introduction) \\
\hline Governance & $\begin{array}{l}\text { Driven by statement of purpose to } \\
\text { deliver public good. Strong and } \\
\text { progressive governance, e.g., } \\
\text { collaborative leadership, } \\
\text { participative decision making, } \\
\text { progressive HR, and sustainable } \\
\text { procurement. }\end{array}$ & $\begin{array}{l}\text { *Statement of Purpose launch (2016) } \\
\text { *Economic contribution £300M (2018) } \\
\text { *Shadow Management Board (2017) } \\
\text { * Senior Management Team “rotating chair” (2018) } \\
\text { *Inclusion of value set in hiring (2018) } \\
\text { * Staff return to work scheme (2018) } \\
\text { * Annual Public Value Impact Report (2018) } \\
\text { *Circular economy refurbishment program (2019-2020) https:// } \\
\text { blogs.cardiff.ac.uk/business-school/2020/02/27/our-circular-economy- } \\
\text { makeover/ }\end{array}$ \\
\hline Teaching & $\begin{array}{l}\text { Develops moral sensitivity } \\
\text { toward-and the capacity } \\
\text { for-economic \& social } \\
\text { improvement. }\end{array}$ & $\begin{array}{l}\text { *PVBS induction seminars \& animated video (2018) } \\
\text { * Student public-value orientation experiment (2018) } \\
\text { * Six new interdisciplinary/challenge-led masters programs, e.g., sustainable } \\
\text { supply-chain management } \\
\text { * Since 2018, all undergraduates offered work placement. } \\
\text { *Annual program review process encourages public-value content and student } \\
\text { projects. }\end{array}$ \\
\hline Research & $\begin{array}{l}\text { Interdisciplinary, challenge-led } \\
\text { research that generates } \\
\text { knowledge about society \& that } \\
\text { informs society \& its constituents. }\end{array}$ & $\begin{array}{l}\text { *Led a major university investment in interdisciplinary, social science-led } \\
\text { research that addresses societal challenges through a new bespoke facility, the } \\
\text { social science park (ongoing from 2013). https://www.cardiff.ac.uk/social- } \\
\text { science-research-park } \\
\text { *New interdisciplinary groups in Corporate Governance, and Responsible } \\
\text { Innovation Network (RIN). This is working with a charity in Eritrea to research } \\
\text { and support women-run microbusinesses. } \\
\text { *Targeted school funding to support public-value research projects including: } \\
\text { i. a team of economists working with colleagues from medicine, dentistry, and } \\
\text { public policy to address alcohol-related crime through a "Cardiff Model" that } \\
\text { involves econometric analysis of the rate of violence-related injury and } \\
\text { alcohol pricing, and } \\
\text { ii. sociologists and human relations specialists working with the UK's Living } \\
\text { Wage Foundation to identify the benefits and challenges that are associated } \\
\text { with applying an ethical wage standard. }\end{array}$ \\
\hline Engagement & $\begin{array}{l}\text { Broad range of partners including } \\
\text { civil society, private, public, \& } \\
\text { third (not-for-profit) sectors, } \\
\text { directed toward social \& } \\
\text { economic improvement. }\end{array}$ & $\begin{array}{l}\text { *New Partnerships } \\
\text { i. } 50 \text {-50 by } 2020 \text { ( } 5050 \text { by2020.org.uk), A campaign to encourage organizations } \\
\text { to increase women's representation in decision-making positions to } 50 \% \text { by } \\
\text { the year } 2020 . \\
\text { ii. Business in the Community (www.bitc.org.uk), a charity that enables } \\
\text { businesses to work together to tackle key social issues, } \\
\text { iii. Enactus (enactus.org), a global community of student, academic, and business } \\
\text { leaders “committed to using the power of entrepreneurial action to transform } \\
\text { lives and shape a better, more sustainable world,” } \\
\text { iv. UNPME (unprme.org), signatories adopt } 6 \text { principles of responsible } \\
\text { management education developed under the coordination of the UN Global } \\
\text { Compact and leading academic institutions. } \\
\text { v. Llamau (llamau.org.uk), a local homeless charity that is the focus of School } \\
\text { fundraising, } \\
\text { vi. CABS Small Business Charter accreditation (one of only } 36 \text { business schools } \\
\text { in the UK) } \\
\text { *Public Value Entrepreneurs (2018) } \\
\text { A diverse group of five entrepreneurs that helps develop links between } \\
\text { researchers, students and small businesses https://www.cardiff.ac.uk/ } \\
\text { business-school/people/entrepreneurs-in-residence. } \\
\text { *Public value fellowships \& engagement project funding (2018) https:// } \\
\text { www.cardiff.ac.uk/business-school/about-us/public-value/public-value- } \\
\text { fellows). } \\
\text { The first round of successful applications produced three projects building } \\
\text { upon existing collaborative research with Disability Rights UK, Anti-Slavery } \\
\text { International, Centre for African Entrepreneurship. }\end{array}$ \\
\hline
\end{tabular}


the School's senior management team. Later that year, he instigated a series of workshops where a wider set of academic and professional services colleagues worked collectively to question, refine, and clarify the School's approach. Some colleagues were immediately enthusiastic and applauded the ideas at meetings-a previously unheard-of event at senior management presentations. Others questioned whether the ideas were compatible with their experience of resource constraints and rising student numbers that had been heralded by the University's instrumental strategy. This skepticism was not unexpected from a school with reputation for both critical management scholarship and public management research (see Table 1), and it reflected the tension that the Dean had recognized from the outset. In response to such questioning, Kitchener restated his view that compliance with university strategy was necessary to maintain the autonomy and resources (including strengthened links with other schools in the University) required for "our radical PVBS" approach.

During internal discussions of the PVBS idea, there were intense debates over the individual terms "public" and "value." Some colleagues feared that the term public signaled a focus on the public sector, others (including some economists) expressed a variety of concerns about using the term value. For many colleagues, however, "public value" became a handy couplet with two attractions: (a) it was intuitively appealing, “who wouldn't want to purposefully try to enhance public good?", and (b) it signaled purposive action away from the University's instrumental strategy. These two impulses lay at the heart of our initial waysetting.

In a second stage of wayfinding, Kitchener sought to build support, from across the parent university and among external stakeholders through presentations to the University's Executive Board and Council, external industry leaders, and politicians. New to university leadership, this activity required the Dean to initiate meetings with a diverse range of academic and professional colleagues. Not everyone initially shared, or understood, Kitchener's enthusiasm for the idea of a PVBS. The two most common anxieties raised were the potential for negative impact on student revenue, and a threat of creating "confusion with the University brand." Over time, Kitchener learned that financial concerns could be allayed by restating CARBS' consistently strong financial contribution record (see Table 1), emphasizing that the explicit PVBS commitment to economic improvement included growing financial contributions to the University, and reporting positive reactions to the PVBS idea that he had experienced at international student recruitment fairs. Kitchener found that concerns about branding could be allayed by stressing that the PVBS' prioritization of interdisciplinary scholarship required the School to work at the heart of the University and build collaboration across it (Currie et al., 2016). This provided a strong point of connection with the work Delbridge had been leading at the university level, particularly his conceptualization and development of the world's first social science park (SPARK; Price \& Delbridge, 2015).

By the Summer of 2016, with support secured from his college head, feedback from consultations increasingly signaled that participants felt that the PVBS approach fitted well, and celebrated the School's tradition, values, and achievements (see Table 1). It was only after 3 years of conceptual waysetting and wayfinding including many "detours and lingerings" (Chia \& Holt, 2009: 173) that in October 2016 Kitchener felt ready to formally launch the School's statement of purpose at a public event (http://www.cardiff.ac.uk/ business-school/about-us/public-valueweblink). Attendees were told that the School existed to:

"Promote economic and social improvement through interdisciplinary scholarship that addresses the grand challenges of our time, while operating a strong and progressive approach to our own governance."

In this, and subsequent presentations, Kitchener also introduced his supporting waymarks to encourage colleagues to develop aligned outcomes in teaching, research, governance, and engagement (see Table 2). As oblique as this combination of purpose statement and waymarks are, they quickly and widely became known as the "School's strategy."

\section{Processes of Collective Wayfinding in Delivering Public Good}

Having articulated the intended direction of change toward delivering public good that was incorporated in ideas of the PVBS, Kitchener's next task was to encourage collective wayfinding to produce aligned innovations across the four main practice areas of the School: governance, teaching, research, and engagement. Table 2 compares Kitchener's waymarks toward the PVBS with the prevailing model, and then summarizes some of the main initiatives that emerged in each functional area. This is not intended to suggest that developments in any area other than governance were instigated by the Dean. Rather, they 
were driven by a range of academic and professional service colleagues finding ways to deliver public good. Our discussion of changes in each area begins below with the School's new formal governance structures and systems, which Kitchener hoped would help provide a supportive context for aligned innovations to emerge organically in teaching, research, and engagement.

Business school governance for public good. One of the distinctive elements of the PVBS is to deliver public good through a progressive approach to self-governance. The starting, but not ending, point is a clear recognition of the School's responsibility to contribute financially to the parent university, and wider economy. As the Dean stated at every opportunity, CARBS has always done this and continued to do so as it moved toward becoming a PVBS. Between 2012 and 2018, CARBS' rate of financial contribution to the University increased from $30 \%$ of revenue to $54 \%$; the School's annual impact on the wider economy is estimated to be $£ 300 \mathrm{M}$ (Jones, 2018). This financial performance was delivered largely through a combination of the following: (a) cost constraint, to meet the School's flat annual expenditure budgets, and (b) recruitment of an additional 550 students per annum, to meet the University's annually increasing revenue target. As dictated by the international recruitment market, most of the additional students are Chinese studying postgraduate economics and finance courses.

From 2015, the School's "achievement" of centrally imposed financial targets was thought by many staff to have caused tensions, for example: rising academic workloads, reduced diversity among the student population, and strains on professional services staff in who deal directly with students. Faculty, publicly and privately, questioned how compatible these conditions were with the School's move to embrace public value. The Dean reiterated to colleagues that he felt this was a cost of the autonomy and resources required to support "our radical PVBS strategy." The Chair of the School's Advisory Board, a senior corporate executive, counseled the Dean that this tension was "what you must accept, and work with, as a wholly-owned subsidiary of a corporate parent.” When, at University meetings, Kitchener repeatedly presented these issues as being risks (to the well-being of colleagues and performance of the school), sympathy was expressed, but no relief offered. These tensions prompted Kitchener and senior leaders to reflect further on how the School organized and managed itself.
Under the instrumental rationality of the traditional governance approach at Cardiff and many other U.K. universities, the combination of strong financial and academic performance and compliance with legal requirements (e.g., financial reporting, human resources) would constitute more than satisfactory outcomes for those Deans engaged to "stand and deliver." However, Cardiff's PVBS statement of purpose inspired many local equality and diversity initiatives (see Table 2), and it provided the impetus for the Deputy Dean to lead the development of a Shadow Management Board (SMB). The aim was to scrutinize the SMT and facilitate more diverse participation in the School's decisionmaking processes. Despite having been advised against this "risky move" by other deans and senior colleagues in the University, it was exactly the type of "local coping action" (Chia \& Holt, 2009: 24) that the waysetting toward a PVBS had sought to prompt. The 14-member SMB includes a mix of junior and senior faculty members and professional services staff from across the School. It comments on the work of SMT (via review of board meeting minutes) and conducts project work. Some examples are a review of the postgraduate teaching portfolio, the development of a school-values set that reflects public value, and an evaluation of the relationship between the School's academic and professional staff. Recommendations from each exercise were adopted following presentation to SMT, and the value set is now included in the person specification of job advertisements. The Chair of the SMB meets with the Dean fortnightly in a spirit of "constructive challenge." In 2017, the initial SMB chair became the first board member to join the SMT, and she was subsequently appointed Dean in 2018 to become the School's first female head. This was a particularly significant outcome given the School's historically poor record of diversity at senior levels (see Table 1).

The School's public-value approach also inspired a range of academic and professional service colleagues to work together to introduce a series of innovations in administrative areas including human resources and procurement (see Table 2). In one example of public value procurement, in the summer of 2019, the School's Estates Committee established a "circular economy" refurbishment program. The two key features were sourcing materials from a local supplier of remanufactured, refurbished, reclaimed, and redistributed products, and having furniture assembled by a local social enterprise that provides employment for people with disabilities. Beyond the public good of supporting sustainable, local 
social-enterprise partners, it was estimated the project was $21 \%$ cheaper than traditional university procurement approaches.

Alongside these aspects of progress, there have inevitably been setbacks. Against a background of worsening university finances, material support for CARBS' public value mission from the parent university has been limited. After receiving initial encouragement from University leaders for the School to bid for PVBS strategy-development funding, an innovative schoolwide "crowd-sourcing" exercise was used to generate ideas for public-value projects. A detailed business case was then prepared for a selection of those projects. After more than a year of development activity, the Dean was told by his head of college that the proposal would not now be considered by the University. This outcome was a major disappointment. It led some colleagues to query why the financial arrangements of the University "didn't allow us to use our money for our development." Others questioned the commitment of the University to the School's PVBS approach and voiced concerns that the University did not want to support a distinct brand/ identity for its business school. Kitchener and other senior leaders were required to dig deep into their reserves of resilience to accept the outcomes, reassure colleagues of more general university support, and promote a counternarrative that collective effort and university resources (including strengthened links with other departments) were required to support our PVBS project.

Teaching and learning for public good. Table 2 outlines examples of innovations at CARBS that colleagues developed to deliver public good through teaching and learning that develops moral sensitivities and capacities to promote economic and social improvement. In common with some aspects of service-learning (Block \& Ona Bartkus, 2019), this pedagogic approach encourages students to adopt a stakeholder (rather than shareholder) perspective, appreciate grand challenges such as sustainability, equality, and climate change, and apply academic theory in a way that enhances public good. At the PVBS, in an innovation designed by colleagues, this begins when all new students participate in an assessment of their orientation toward public value (prosocial) values at induction. It is hoped that a second assessment in their final year (2020-2021) will show that the public-value orientation will have strengthened among students. In terms of curricula development, public value is now a key theme in the annual review of all programs, encouraging multidisciplinary and challenge-led content. The aim is to help students develop a better understanding of the marginalized, who face challenges such as a lack of social protection, poor working practices, and wage stagnation. In one example of the School's version of the service-learning approach, project work on the MBA Management Consulting module now focuses on local charities and NGOs.

Despite the innovations outlined above, three main factors have combined to slow the development of public good delivered by CARBS' teaching and learning. First, the School's academic leaders of teaching and learning were challenged by the demands of the "day job" (including completing a long-running review of undergraduate teaching, introducing new masters programs, managing rising student numbers, quality assurance of learning, and AACSB re-accreditation). Second, with institutional publication pressures, rising student numbers, and increasing workloads, there is little time - and one might argue limited incentive-for individual academics to alter curricula. Third, professional accreditations restrict the extent to which some curricula can change (e.g., accounting).

Research for public good. The School has traditionally supported the research activity of its staff in three main ways: allocating time for research in faculty workloads, providing research-active staff with an individual research budget, and through a variety of funded schemes. Following the launch of the PVBS in 2016, the School's Research Committee decided to redirect the discretionary research budget to support interdisciplinary studies that address society's grand challenges. Of course, faculty are still encouraged to pursue their own research interests, and much public- value research had been conducted in the School before this. However, school funding now supports a distinctive and growing portfolio of public-value research projects, including those summarized in Table 2. The prioritization of public-value criteria in the allocation of research funding was consistent with, and complementary to, initiatives at the institutional level in which CARBS has played a leading role, including the development of SPARK and the creation of two major new interdisciplinary groups in Corporate Governance and Responsible Innovation led by CARBS staff.

A further distinctive feature of research at CARBS has been the development of scholarship in public value. As part of the School's wayfinding, a public-value seminar series was established. This has seen strong participation from within CARBS, and the attraction of leading speakers from around the world, including John Brewer (Queen's University Belfast) whose work sat at the heart of the PVBS initiative. In one outcome, colleagues from the School's marketing section were inspired to edit a collection of conceptual and empirical work on public 
value (Lindgreen et al., 2019) that includes a contribution from Kitchener (2019), providing a blueprint for a social science strategy based on public value. In keeping with the School's traditions in critical management and open debate (see Table 1), some colleagues have contributed to our wayfinding through written pieces that question the potential for the PVBS in the current political economy of higher education (Marinetto \& Dallyn, 2017).

Engagement for public good. In addition to maintaining conventional elite engagements (including hosting the Institute of Directors in Wales), CARBS has increasingly promoted economic and social improvement through formal partnerships with the diverse band of "fellow travellers" summarized in Table 2. Although some of these are international in scope, (e.g., UNPRME), others are local, including the School's partnership with Llamau, a Welsh homeless charity. At the end of the successful tenure of the previous chair of the School's advisory board, he was replaced by Adele Blakeborough, MBE, who is CEO of Social Business Trust. Partners such as Adele and the School's new public-value entrepreneurs (see Table 2) are important to the PVBS project in a number of ways: They give credibility to an intrapreneurial approach that challenges internal assumptions and practices; they provide examples and learning opportunities; and they give "moral support" to leaders when battling against barriers to change.

In 2017, to further encourage broader and deeper external relations that contribute to public good, the School established competitive public-value fellowships and engagement-project funding streams open to all researchers. The first round funded projects !the employment of disabled people, forced labor, and entrepreneurial opportunities for disadvantaged populations, respectively (see Table 2). Although any of these projects would have been possible under the School's previous approach (and indeed some of the work represents a continuation of activity), taken together, they represent a strong indication of the nature and breadth of public-good engagement activity that the School promotes.

Indicators of progress. From the middle of 2017, there were indications to suggest positive impacts of CARBS' substantively rational action and approach to change management. Internally, staff satisfaction (as measured by the annual University survey) improved despite a context of colleagues' rising concerns about student numbers, workload, and the University's weakening financial position. Within the parent University, the School's strategy was formally commended by the Executive Board and Council, it influenced the development of the University's strategy (which began to talk about "civic mission” rather than "engagement"), and it formed the basis of the University's nomination of CARBS, for the Times Higher Education Business School of the Year Award. The PVBS idea also received strong public endorsement from sector leaders, including Sir Michael Barber, Head of the U.K. Office for Students (the English higher education regulator), who said on a visit to the School, "I love the idea of a public value business school." In 2017, CARBS was listed for the first time in all of the Times Higher Education, QS, and Shanghai world top-100 rankings, and the School's 2018 AACSB peer-review team provided a strong endorsement of the PVBS approach.

The development of indicators to capture and celebrate CARBS' enhancement of public good also began in 2017 when a Director of Public Value was appointed. A professor of economics with expertise in the measurement of social impact took the role and produced the first annual public-impact report (Jones, 2018). This exercise is the first known attempt to measure and narrate a business schools' public good against three indicators: (1) economic impact, independently estimated as a $£ 300 \mathrm{M}$ contribution to the economy with 1,300 jobs supported; !sustainability, annual carbon footprint estimated to be 15,000 tons CO2e, and (3) staff attitudes, internal survey reporting agreement with the statement that "the School's strategy is shaping responses to diverse social challenges" (3.8/5 with 5 strongly agree). A major challenge to emerge from this work was the finding that the largest contributor to the School's carbon footprint is the travel of international students who are, of course, its largest source of revenue.

By the end of 2018, there were signs that CARBS students were both aware of, and valued, the PVBS approach to teaching. For example, when speaking at a School prize-giving event, a student chose to tell her audience:

"Cardiff Business School has a public value policy that sees us students taught to create not only economic value, but social value as well. It's what makes the School so extraordinary." - Erin Mina Barber, Cardiff MBA student 2018.

Although some of these outcomes were never the purpose of the substantively rational action undertaken, they may indicate that it is not entirely incompatible with the instrumental ends of many business schools (Arielli et al., 2016).

\section{LEARNING FROM THE EXPERIENCE OF WAYSETTING AND WAYFINDING}

Since writing this paper in late 2019, we have both returned to CARBS" ranks of the "lumpen professoriate" 
(Gehrke \& Kezar, 2015: 93), having reached the University's time limits on our leadership roles. To contribute to this Special Issue's theme of rationality in management education and learning, we report an analytic autoethnography (Anderson, 2006) in which we revisit Weber's (1978) distinction between instrumental and substantive rationality and reflect on our forays into university leadership. The outcome is a conceptually underpinned explanation for the mounting criticism of business schools and the basis for the new business school approach presented here. Our initial conceptual work (establishing the underlying causes of some of the critiques of contemporary business schools) provided the basis for our waysetting; that is, the process of establishing both a values-based (substantively rational) orientation to action, and an oblique sense of the direction of change toward delivering a business school for public good. We have found the analytic autoethnographic approach reported here of considerable value in developing and telling "our version" of the story in a way that has allowed us to produce theoretical insights into the organizational processes at its heart. It has also helped us in some of our own sense making. In retrospect, we can now see more clearly how our academic work (e.g., Biggart \& Delbridge, 2004; Delbridge, 2014; Kitchener, 2002; Kitchener et al., 2000) informed our thinking and actions on the more practical matters at hand. As business school academics contend with increasingly challenging conditions, including the mounting criticisms of business schools and global crises such as climate change and the Coronavirus pandemic, we believe that critical and reflexive analysis of ourselves and our institutions should play an importance role in imagining and shaping our sustainable futures. In our view, these futures will require institutional and systemic change. ${ }^{1}$ Our analysis shares with Harley

\footnotetext{
${ }^{1}$ During the final stages of writing this article, Delbridge was co-convenor of the 15th Organization Studies Summer Workshop 2020 on Organizing Sustainably. It should have been held on Crete but, due to the coronavirus, was held virtually. Reflections on the pandemic were rife throughout the event, and the need for radical and sustainable change to address a variety of sustainability issues was a common theme. Discussions often turned to the value of imagining alternative futures and reflecting on utopia as a way of catalyzing such transformations, and to the responsibility of academics to contribute to those transformations in meaningful ways. This led the convenors, Elke Schussler, Charlene Zietsma, Andi Pekarek, Markus Helfen, and Rick Delbridge, to create an open platform for the exchange of ideas, teaching and research resources, and the hosting of blogs. Utopia Platform: Imagining Transformations (UP:IT, https://utopiaplatform.wordpress.com).
}

(2019) the conclusion that the current crisis of confidence in business schools arises from their increasingly common instrumental focus on achieving outcomes such as ranking position and student revenue (Arielli et al., 2016). Although Harley (2019) offers three proposals for how senior business school academics might change their behaviors, we provide a more ambitious alternative model for business schools themselves. For relief to be sought through the substantively rational pursuit of ethical values, institutional and systemic change will be required. In elaborating this position, we have sought to illustrate how a substantively rational business school can employ reason and deliver positive change, because it directly orders action in pursuit of a value postulate (Kalberg, 1980; Biggart \& Delbridge, 2004). In stark contrast to the calculus of instrumental rationality shared by our university and much of the global political economy of higher education, the probability of success is not critical to substantive rationality. We have come to recognize our change project at Cardiff as representing an attempt to introduce a new model of business school based on the substantively rational pursuit of public good.

In reflecting on our experiences of moving toward a PVBS, the case reported here provides a rare account of an oblique process of change. In contradistinction to the NPM-style strategic approach of our corporate parent, the PVBS was not pursued through a combination of attempts to enhance managerial control over professional work and achieve KPIs. Rather, as Kay (2010: 16) describes, Kitchener's oblique approach recognized "that what we want... has many elements. We will never succeed in specifying fully what they are, and to the extent we do, we discover that they are often inconsistent and incompatible." The approach was motivated toward the ethical value of delivering public good: a "direction" for value-orientated action, rather than specific means and outcomes. Such an approach is consistent with substantive rationality because, as Kalberg (1980: 1155) observes, substantive rationality and rationalization processes based on it always exist in reference to ultimate points of view, or "direction" as there is an infinite of potential value "postulates." Nonetheless, as our case shows, the approach reported here was methodical and the consequence of conscious patterns of thinking and action (Kalberg, 1980: 1161).

As we anticipated from the outset, a number of tensions arose from trying to introduce a substantively rational model and engaging in an oblique change process within an institutional context that focuses on the instrumental pursuit of outcomes. The most fundamental arose from Kitchener's resolution of his “dean’s dilemma” by resigning himself to an approach 
that led to the School's accomplishment of centrally imposed KPIs to provide the autonomy and resources to support the School's pursuit of its substantively rational pursuit of public good. This compromise created an enduring tension that continues to shadow the development of the PVBS at Cardiff. For many colleagues, this surfaces most clearly when the School's substantively rational commitment to enhance public good collides annually with the University's demands for the instrumentally rational achievement of outcomes, including growing international postgraduate student revenue. This tension clearly threatens the stability of the PVBS and will continue to frame concerns over rising academic workloads and diversity among the student population. Of crucial importance to the prospective sustainability of the PVBS program, the first chair of the shadow management board was later selected by the University to succeed Kitchener as Dean, on a mandate to continue the PVBS project.

Our case study shows clear indications of progress toward the PVBS goal of enhancing public good through progressive approaches to governance, interdisciplinary and challenge-led research, engagement activity with a broader range of partners, and teaching that develops a moral sensitivity to the promotion of economic and social improvement. However, role strain on teaching leadership, limited capacity/incentive for academics to alter curricula, and regulatory limits on the scope for changes to some curricula (e.g., accounting) have combined to slow progress in that area. Because these challenges are common among many business schools, they seem likely to influence any similar attempts to introduce values-based approaches elsewhere. If not addressed of course, this situation could dislocate teaching operations from other school functions.

Our reporting of an oblique strategic approach at CARBS elaborates and extends three aspects of Chia and Holt's (2009) "strategy without design" perspective. First, we illustrate empirically how an oblique approach to change can accommodate the two forms of action that they differentiate (p. 92): the purposive action we took away from prevailing instrumental approaches, and the purposeful action we took to move toward the desired PVBS. Second, in an extension of Chia and Holt's concept of wayfinding, we introduce the term "waysetting" to capture the purposeful action that we engaged in. Third, we provide an empirical account of the waysetting and collective wayfinding through which change progressed tentatively and iteratively, drawing on the distributed wisdom (Nonaka \& Toyama, 2007) of the School's members to develop innovative and aligned outcomes through their "local coping actions” (Chia \& Holt, 2009: 24).

\section{CONCLUSIONS}

The emergent approach at the Cardiff PVBS-based on the substantive rationality of pursuing public good and a complementary, substantively rational, approach to managing change-may offer one direction for the leaders of "lost" schools to "head" toward (Alajoutsijarvi et al., 2018: 219). It is, however, no panacea for all business schools' ills. Neither will it be applicable across the full variety of schools operating globally (Kaplan, 2018). A number of contextual features supported the Cardiffmodel. First, the Dean was allowed considerable temporal freedom to develop his approach; a necessary condition to accommodate waysetting and wayfinding that involved many "detours, lingerings, and directional changes” (Chia \& Holt, 2009: 173). Second, Kitchener's 2013 strategic review revealed both that the Schools' traditional characteristics might be receptive to the PVBS idea (e.g., broad disciplinary base, European cultural orientation toward plurality, a heterogeneous research focus, and an appetite for progressive governance), and that it had knowledgeable and committed colleagues who did not like the form of managerialism that had come to pervade U.K. higher education in general, and increasingly, their own university.

Among CARBS academics, the PVBS idea came to hold two attractions. First, the purposeful movement toward enhancing public good was intuitively appealing, especially for those colleagues who embody social science's founding moral commitment to human betterment (Brewer, 2013). Second, the PVBS signaled purposive action away from the University's instrumental strategy. Harley's (2019) analysis suggests this combination of aspirations is not restricted to Cardiff academics. Because so many colleagues "bought into" the aspiration for a PVBS with its combination of purposive and purposeful direction, there emerged a participative process of shaping the nature of the change and the creative outcomes of aligned changes across teaching, research, governance, and engagement.

The substantively rational direction and process of change at Cardiff may have less resonance in business schools with a narrower focus (because of reduced opportunities for challenge-led and interdisciplinary scholarship), and/or those that have a North American cultural orientation which is, traditionally, more closely wedded to business and notions of instrumental rationality and the primacy of shareholder value (Kaplan, 2018). However, key components of the PVBS approach are closely aligned with a heterogeneous cluster of epistemic, theoretical, and methodological traditions including participatory action research, indigenous methodologies, feminist studies, and decolonial 
approaches (Lozano, 2018). Because many of those approaches emerged from the Global South, this may provide fertile ground for nurturing the seed of substantively rational business school approaches.

Wherever such change is attempted, faculty will be well placed to serve both as the collective "conscience" of business schools, and in providing the collaborative wisdom needed to shape and enact moves away from the instrumentally rational political economy of higher education. In turn, they will be offered a greater variety of paths to success in academic life based on longerterm relationships with colleagues and external partners which are of intrinsic value, rather than simply means to achieve "high-ranked" outputs and meet corporate KPIs. Such moves will challenge tendencies toward unreflexive managerialism, promoting instead, forms of substantive rationality that can provide the basis from which business schools may more fully contribute to the public good.

\section{REFERENCES}

Aguinis, H., Shapiro, D., Antonocopoulou, E., \& Cummings, T. 2014. Scholarly impact: A pluralist conceptualisation. Academy of Management Learning \& Education, 13(4): 623-639.

Akrivou, K., \& Bradbury-Huang, H. 2015. Educating integrated catalysts: Transforming business schools toward ethics and sustainability. Academy of Management Learning \& Education, 14(2): 222-240.

Alajoutsijarvi, K., Juusola, K., \& Siltaoju, M. 2015. The legitimacy paradox of business schools: losing by gaining? Academy of Management Learning \& Education, 14(2): 277-291.

Alajoutsijarvi, K., Juusola, K., \& Siltaoju, M. 2018. Shaking the status quo: Business accreditation and positional competition. Academy of Management Learning $\mathcal{E}$ Education, 12(2): 203-225.

Anderson, L. 2006. Analytic Autoethnography. Journal of Contemporary Ethnography, 35(4): 373-395.

Arielli, S., Sagov, L., \& Cohen-Shalem, E. 2016. Values in business schools: The role of self-selection and socialisation. Academy of Management Learning $\&$ Education, 15(3): 277-291.

Atkinson, P. A., Coffey, A., \& Delamont, S. 2003. Key themes in qualitative research: Continuities and change. Walnut Creek, CA: AltaMira Press.

Bartlett, C. A., \& Ghoshal, S. 1994. Changing the role of top management: Beyond strategy to purpose. Harvard Business Review, (November-December): 79-88.

Biggart, N. W., \& Delbridge, R. 2004. Systems of exchange. Academy of Management Review, 29(1): 28-49.
Block, E. S., \& Ona Bartkus, E. 2019. Learning to serve: Delivering partner value through service-learning projects. Academy of Management Learning $\&$ Education, 18(3): 361-387.

Brewer, J. D. 2013. The public value of the social sciences. London: Bloomsbury.

Cardiff Business School. 2013. Senior management team meeting notes, October. Available from first author on request.

Cardiff University. 2012. 2012-2017 The way forward. Cardiff: Cardiff University.

Carruthers, B., \& Espeland, W. 1991. Accounting for rationality: Double-entry bookkeeping and the rhetoric of economic rationality. American Journal of Sociology, 97: 31-69.

Chia, R. C. H., \& Holt, R. 2009. Strategy without design: The silent efficacy of indirect action. Cambridge: Cambridge University Press.

Currie, G., Davies, J., \& Ferlie, E. 2016. A call for universitybased business schools to lower their walls: Collaborating with other academic departments in pursuit of social value. Academy of Management Learning $\&$ Education, 15(4): 1-14.

Delbridge, R. 2014. Promising futures: CMS, postdisciplinarity and the new public social science. Journal of Management Studies, 51(1): 96-117.

Derry, R. 1989. An empirical study of moral reasoning among managers. Journal of Business Ethics, 8: 855-862.

Ferlie, E., McGivern, G., \& De Moraes, A. 2010. Developing a public interest school of management. British Journal of Management, 21: 60-70.

Fotaki, M., \& Prasad, A. 2015. Questioning neoliberal capitalism and economic inequality in business schools. Academy of Management Learning \& Education, 14(4): 556-575.

Gair Rhyd, 2012. Huw Edwards speaks to Cardiff University Vice chancellor about university's future. https://cardiffstudentmedia.co.uk/gairrhydd/huwedwards-speaks-to-cardiff-university-vice-chancellorabout-universitys-future/ Accessed 31/3/21.

Gehrke, S., \& Kezar, A. 2015. Unbundling the faculty role in higher education: Utilizing historical, theoretical and empirical frameworks to inform future research. Higher Education Handbook: Theory and Research, 30: 93-150.

Ghoshal, S. 2005. Bad management theories are destroying good management practices. Academy of Management Learning \& Education, 49(1): 75-91.

Harley, B. 2019. Confronting the crisis of confidence in management studies: Why senior scholars need to stop setting a bad example. Academy of Management Learning \& Education, 18(2): 286-297.

Jones, C. 2018. Cardiff business school public value report. Cardiff: Cardiff Business School. 
Joullie, J. E. 2016. The philosophical foundations of management thought. Academy of Management Learning \& Education, 15(1): 157-179.

Kalberg, S. 1980. Max Weber's types of rationality: Cornerstones for the analysis of rationalization processes in history. American Journal of Sociology, 85(5): 1145-1179.

Kaplan, A. 2018. A school is a 'building that has four walls ...with tomorrow inside': Toward the reinvention of the business school. Business Horizons, 61: 599-608.

Kay, J. 2010. Obliquity: Why our goals are best achieved indirectly. London: Profile Books.

Khurana, R. 2007. From higher aims to hired hands: The social transformation of American business schools and the unfulfilled promise of management as a profession. Princeton, NJ: Princeton University Press.

Kitchener, M. 2002. Mobilizing the logic of managerialism in professional fields: The Case of academic health center mergers. Organization Studies, (23)3: 391-420.

Kitchener, M. 2019. The public value of social science: From manifesto to organisational strategy. In A. Lindgreen, N. Koenig-Lewis, M. Kitchener, J. D. Brewer, M. H. Moore, \& T. Meynhardt (Eds.), Public value: Deepening, enriching, and broadening the theory and practice:301-315. Abingdon: Routledge.

Kitchener, M., Kirkpatrick, I., \& Whipp, R. 2000. Supervising professional work under new public management: Evidence from an invisible trade. British Journal of Management, 11(3): 213-226.

Learmonth, M., \& Humphreys, M. 2011. Autoethnography and academic identity: Glimpsing business school doppelgängers. Organization, 19(1): 99-117.

Lozano, A. A. 2018. Reframing the public sociology debate: Towards collaborative and decolonial praxis. Current Sociology, 66(1): 92-109.

Marinetto, M., \& Dallyn, S. 2017. The public value of academic research: A critique of John Brewer's public value social science. Working paper, Cardiff Business School.

Moore, M. H. 1995. Creating public value: Strategic management in government. Cambridge, MA: Harvard University Press.
Nonaka, I., \& Toyama, R. 2007. Strategic management as distributed practical wisdom (phronesis). Industrial and Corporate Change, 16(3): 371-394.

Parker, M. 2018. Shut down the business school: What's wrong with management education. London: Pluto.

Pettigrew, A. M., \& Starkey, K. 2016. The legitimacy and impact of business schools: Key issues and a research agenda. Academy of Management Learning $\mathcal{E}$ Education, 15(4): 649-664.

Price, A., \& Delbridge, R. 2015. Social science parks: Society's new super labs. London: Nesta.

Watson, T. J. 2009. Narrative life story and manager identity: A case study in autobiographical identity work. Human Relations, 62(3): 425-452.

Weber, M. 1978. Economy and society. Berkeley: University of California Press.

Womack, J. P., Jones, D. T., \& Ross, D. 1990. The machine that changed the world. New York: Rawson Associates.

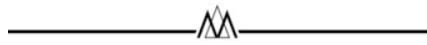

Martin Kitchener, FCIPD, FLSW, FAcSS, earned his PhD at Cardiff Business School where he is now professor of management. He is currently collaborating on a European Union Horizon 20/20 study of public service innovations that are co-created with citizens (COGOV), and he serves as Chair of the Chartered Association of Business Schools' Task Force on Business Schools for the Public Good.

Rick Delbridge, FAcSS, FBAM, FLSW, earned his $\mathrm{PhD}$ at Cardiff Business School where he is now professor of organizational analysis. His research interests include work and workplace relations, critical human resource management, the management of innovation and theorizing organization. He has published on these and related topics in Academy of Management Review, Human Relations, Journal of Management Studies, Organization Science and Organization Studies among others. 
Copyright of Academy of Management Learning \& Education is the property of Academy of Management and its content may not be copied or emailed to multiple sites or posted to a

listserv without the copyright holder's express written permission. However, users may print, download, or email articles for individual use. 